\title{
Melting processes in veined lithospheric mantle in cratonic and non-cratonic settings
}

\author{
Foley, S.F. ${ }^{1}$, Musselwhite, D.S. ${ }^{1}$ and van der Laan, S.R. ${ }^{2}$ \\ 1. Mineralogisch-Petrologisches Institut, Universität Götingen, Goldschmidtsr.1, D-37077 Göttingen, Germany \\ 2. Dept. Earth Sciences, Universiteit Utrecht, Budapestlaan 4, TA 3508 Utrecht, Netherlands
}

Partial melting of veins in the lower lithosphere consisting dominantly of clinopyroxene and hydrous minerals, and subsequent reaction of vein-derived melts with the peridotite wall-rocks may be the best way to explain the geochemical characteristics of lamproites and kimberlites. A melt which forms in a vein with different mineralogy to peridotite will not be in equilibrium with the peridotite and so the two will react during the melting process at a temperature below the melting point of peridotite. This reaction process should not be confused with those invoked recently to explain calc-alkaline melts or the production of olivine-rich regions within peridotites, since it is an integral part of the melting process rather than taking place later during transport of melt towards the Earth's surface.

The ultimate origin of the veins a consequence of a transition between channelled flow regime in the lithosphere and porous flow regime at deeper levels below continental regions. This reference to flow regimes does not mean that melt is always present in these areas, but merely that these flow regimes apply when melting occurs due to either the episodic passing of a mantle plume or to extension within the overlying lithosphere. Remelting of the veins at a later stage will result in magmatic effects whose nature and magnitude depend on the extent of the heating and on the tectonic environment. In cratonic regions, restricted heating will cause local mantle metasomatism related to the progression of veining to higher and wider lithospheric levels; more extensive heating will produce surface magmatic activity such as lamproites and kimberlites, and maybe various types of more voluminous magmas with incompatible element-rich signatures, such as alkaline picrites (Foley et al., 1998).

\section{Methods of investigation of veined mantle melting}

The major questions for research before these melting mechanisms and their chemical effects on magmas can be quantified are the melting temperatures and melt compositions produced by various likely vein assemblages, the relation of these melting temperatures to the ambient geotherm, the exact melting reactions and identity of the residual minerals, the mechanisms of infiltration of these melts into wall-rocks, the nature of the ensuing hybridisation reactions between melts and wall-rocks, and the timing of the extraction of the "primary" melt from the source region. The petrology group in Göttingen is tackling several of these lines of investigation by means of experimental melting of vein assemblages, studies of melt infiltration in natural ultramafic rocks, and experimental studies of melt morphology and surface energies between melts and the mineral constituents of relevant ultramafic rocks. Here, we concentrate on the determination of melting temperatures and the compositions of veinderived melts, and derive a few general interpretations from the results.

\section{Summary of experimental results on melting of vein assemblages}


As a first step towards the quantification of these processes, we have carried out melting experiments on model vein assemblages chosen to represent veins in the lower lithosphere beneath cratons and in the lower continental lithosphere away from the cratons. The "cratonic" assemblages consist of a third each of $\mathrm{Cpx}$, phlogopite $(\mathrm{Phl})$ and potassic richterite $(\mathrm{KR})$ with or without accessory rutile $(\mathrm{Ru})$, ilmenite (Ilm) or apatite (Ap) (Foley, et al., 1995), whereas the "non-cratonic" veins consist of various proportions of low-Ti pargasite (Am), Ap, Cpx and biotite (Mica). The experimental approach consists of two series of experiments: (1) experiments to determine the solidus temperature, and (2) extraction trap experiments to isolate melts as larger areas of glass for major and trace element analysis. This circumvents the problem of modification of melt compositions during quenching after the experiment.

Table 1 lists several melt compositions obtained as averages of multiple analysis points on glasses in melt traps from experiments on "cratonic" (analyses 1-3) and "non-cratonic" veins (4-7). The most important generalities which can be made about the melting processes and melt compositions are:

(1) Melting points do not differ greatly as a function of vein assemblage as long as amphibole or mica is present. Melting points at $15 \mathrm{kbar}$ are in the range $1025-1075^{\circ} \mathrm{C}$ for assemblages containing either alkali or calcic amphiboles, whereas mica-pyroxenites melt at $1100-1125^{\circ} \mathrm{C}$ at the same pressure. Experiments at $50 \mathrm{kbar}$ on the "cratonic" assemblages show that they exhibit a melting curve with a PT slope much steeper than geothermal gradients, as is typical of dehydration melting reactions. meaning that the temperature perturbation necessary to cause melting in the veins is reduced towards higher pressures and thus at lower levels of the lithosphere.

(2) Melt compositions are primarily controlled by the identity and composition of the amphibole, if present. Cratonic vein assemblages with alkali amphibole melt incongruently to melts rich in $\mathrm{SiO}_{2}$ and $\mathrm{K}_{2} \mathrm{O}$, but poor in $\mathrm{CaO}$ and $\mathrm{Al}_{2} \mathrm{O}_{3}$ (Table 1). Non-cratonic vein assemblages with calcic amphiboles form melts with $37-39 \% \mathrm{SiO}_{2}, 5-6 \% \mathrm{TiO}_{2}$ and only $2-3 \% \mathrm{P}_{2} \mathrm{O}_{5}$ despite high apatite contents in the starting assemblage. The presence of additional accessory minerals such as $\mathrm{Fe}$ - and Ti-oxides does not greatly affect melting temperatures, but melt compositions (both major and trace elements) are strongly influenced by the rapid elimination of these phases during melting (see Table 1, melts 1-3). Vein-melt compositions in their unreacted form are unlike all surface melts. The "cratonic" melts most resemble leucite lamproites, although they diverge from such compositions when accessory phases are also present in the veins. Melts from "non-cratonic" vein assemblages are broadly similar to nephelinites and melilitites. Differences between partial melts of such veins (provided they are amphibole-bearing) and those of amphibole peridotites are likely to be subtle, because both are controlled principally by high modal melting of calcic amphibole.

\begin{tabular}{|l||c|c|c||c|c|c|c|}
\hline \multicolumn{1}{|c||}{} & \multicolumn{3}{c||}{ Cratonic veins } & \multicolumn{4}{c|}{ Non-cratonic veins } \\
\cline { 1 - 8 } Expt.No & 1 & 2 & 3 & 4 & 5 & 6 & 7 \\
\hline Minerals & $\begin{array}{c}\mathrm{Cpx}+\mathrm{Phl}+ \\
\mathrm{Kr}\end{array}$ & $\begin{array}{c}\mathrm{Cpx}+\mathrm{Phl}+ \\
\mathrm{KR}+\mathrm{Ilm}\end{array}$ & $\begin{array}{c}\mathrm{Cpx}+\mathrm{Phl}+ \\
\mathrm{KR}+\mathrm{Ru}\end{array}$ & $\mathrm{Am}+\mathrm{Ap}$ & $\begin{array}{c}\mathrm{Am}+\mathrm{Ap}+ \\
\mathrm{Cpx}\end{array}$ & $\begin{array}{c}\mathrm{Am}+\mathrm{Ap}+ \\
\mathrm{Mica}\end{array}$ & $\begin{array}{c}\mathrm{Am}+\mathrm{Ap}+ \\
\mathrm{Mica}{ }^{*} \mathrm{Cpx}\end{array}$ \\
\hline Temp. & 1050 & 1025 & 1025 & 1100 & 1100 & 1100 & 1125 \\
\hline $\mathrm{SiO} 2$ & 56.03 & 50.22 & 50.78 & 36.76 & 37.64 & 38.73 & 37.30 \\
$\mathrm{TiO} 2$ & 1.59 & 10.61 & 11.36 & 6.18 & 5.39 & 5.17 & 6.06 \\
$\mathrm{Al} 2 \mathrm{O} 3$ & 4.81 & 2.71 & 2.80 & 13.04 & 13.18 & 14.16 & 15.66 \\
$\mathrm{FeO}$ & 5.81 & 7.20 & 4.97 & 12.77 & 12.63 & 12.41 & 10.33 \\
\hline
\end{tabular}




\begin{tabular}{|l||c|c|c||c|c|c|c|}
\hline $\mathrm{MgO}$ & 8.56 & 8.81 & 8.82 & 9.59 & 7.43 & 6.54 & 13.95 \\
$\mathrm{CaO}$ & 3.25 & 4.40 & 6.48 & 14.56 & 15.19 & 14.71 & 6.94 \\
$\mathrm{Na} 2 \mathrm{O}$ & 4.82 & 4.54 & 5.17 & 2.76 & 2.69 & 1.90 & 2.15 \\
$\mathrm{~K} 2 \mathrm{O}$ & 13.75 & 10.56 & 9.95 & 1.83 & 1.89 & 2.95 & 5.06 \\
$\mathrm{P} 2 \mathrm{O} 5$ & & & & 1.78 & 3.25 & 2.91 & 2.05 \\
\hline \multicolumn{1}{|c|}{$\mathrm{Mg} \#$} & 72.4 & 68.6 & 74.7 & 64.0 & 58.2 & 55.5 & 76.2 \\
\hline
\end{tabular}

Table 1: Major element compositions of melts of vein assemblages derived from multiple electron probe analyses of glasses in melt traps (all experiments at 15kbar). Cpx=clinopyroxene; $\mathrm{Phl}=$ phlogopite, Ilm=ilmenite; $\mathrm{Ru}=$ rutile; $\mathrm{KR}=$ alkali amphibole (potassic richerite); Am=calcic amphibole (low-Ti pargasite); Ap=apatite; Mica=biotite. Melts from non-cratonic assemblages also contain 1.8-3.2 wt\% fluorine. $\mathrm{Mg} \#=100 \mathrm{Mg} /(\mathrm{Mg}+\mathrm{Fe})$

(3) Progressively increasing degree of melting in the vein assemblage leads to an increase in the $\mathrm{Mg \#}$

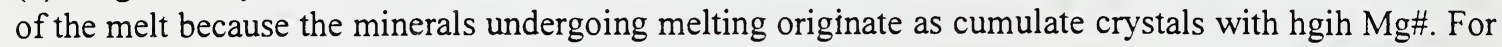
example, the $\mathrm{Mg \#}$ of 72 for melt composition 1 in Table 1 corresponds to $17 \%$ melting, whereas this increases to 90 by $40 \%$ melting $\left(\right.$ at $1200^{\circ} \mathrm{C}$ ). These $\mathrm{Mg \#}$ are much higher than those generally expected for mantle melts.

(4) In terms of potential reaction between vein-derived melts and peridotite wall-rocks, the melts are saturated with Cpx and olivine (formed by incongruent of melting of amphibole and particularly mica), so that it is chiefly Opx and the alumina-rich phases garnet or spinel in the wall-rock which are endangered. However, for the "cratonic" melts of KR-bearing assemblages Opx will probably show little reaction with a melt with $56 \% \mathrm{SiO}_{2}$, so that reaction with $\mathrm{Ol}$ and Opx may be restricted to an exchange of components to achieve equilibrium values for $\mathrm{Mg \#}$ and compatible trace elements (CTE), such as $\mathrm{Ni}$ and $\mathrm{Mn}$. Furthermore, because the $\mathrm{Mg} \#$ of the incoming melt is higher than the value for melts in equilibrium with peridotite, the reaction will cause $\mathrm{Mg} / \mathrm{Fe}$ in the melt to decrease, which will help to keep the melt from crystallising ( $\mathrm{Mg}$ is a more refractory component than $\mathrm{Fe}$ ) and enable the reacted melt to move further. Zoning of $\mathrm{Ol}$ and $\mathrm{Opx}$ in $\mathrm{Mg \#}$ and CTEs may prove to be a useful tool to recognise melt infiltration into peridotites where other evidence for infiltration has not been preserved.

\section{Other investigations and applications}

The possible application of vein plus wall-rock melting to a variety of other rock types and tectonic settings such as flood basalt provinces (Foley, 1992; Foley et al., 1998), subduction-related volcanism (Luhr, 1997) and even some ocean-island basalts can be considered, which widens the palette of possible vein assemblages. The assemblages studied here were chosen as likely candidates for veins in the continental lithosphere which melt at the lowest temperatures. Mica-pyroxenites are thought to be produced in subduction zones, and Phl-, Ilm- and Am-bearing veins are found as xenoliths in these regions (e.g. Stern et al., 1989). However, any assemblages whose melting temperatures are appreciably below that of peridotite but only marginally above the ambient geotherm will be important melt producers, even if they form only a relatively small proportion of all mantle vein assemblages. Of the possibly important vein assemblages not yet covered in our study, garnet-bearing assemblages, especially garnet pyroxenites, feature prominently in xenolith suites. Experimental determinations of 
their melting points to date give diverse results (see compilation by Hirschmann and Stolper, 1996), whereby the lowest temperature is comparable to the highest temperature melting points for the amphibole-bearing assemblages in our study.

A central question in the reaction process between melt and wall-rock is the infiltration mechanism, which affects both the extent of wall-rock reaction possible and the timing of ultimate melt extraction from the source region. It has become accepted to invoke porous flow theory in which dihedral angles between melts and minerals determine whether infiltration can occur; the speed and thus volume of melt migration is controlled largely by the melt viscosity. However, recent studies of experimental charges have recognised an array of coexisting melt morphologies (Drury and Fitzgerald, 1996; Cmiral et al., 1998) which may cause the effectively extractable melt fraction to be larger than hitherto expected. Variance of surface energies as a function of crystallographic orientation also needs to be considered because of the strong preferred orientation to be expected in veins formed by wallaccumulation of crystals in these parageneses.

\section{References}

Cmiral, M., Fitzgerald, J.D., Faul, U.H. and Green, D.H., 1998, A close look at dihedral angles and melt geometry in olivine-basalt aggregates: a TEM study: Contrib. Mineral. Petrol. (in press)

Drury, M.R. and Fitzgerald, J.D., 1996, Grain boundary melt films in an experimentally deformed olivine-orthopyroxene rock: implications for melt distribution in upper mantle rocks: Geophys. Res. Lett 23, 701-704.

Foley, S.F., 1992, Vein-plus-wall-rock melting mechanisms in the lithosphere and the origin of potassic alkaline magmas: Lithos $28,435-453$.

Foley, S.F., van der Laan, S.R. and Horn, I., 1995, Experimental melting reactions in amphibole- and phlogopite-baring mantle vein assemblages and the trace element compositions of derived partial melts: 6th Int. Kimberlite Conf. Ext. Abs, 161-163

Foley, S.F., Glaser, S.M. and Andronikov, A.V., 1998, Non-cratonic garnet peridotites from rifted continental settings in Vitim, Siberia (Baikal Rift) and East Antarctica (Lambert-Amery Rift), this volume.

Hirschmann, M.M. and Stolper, E.M., 1996, A possible role for garnet pyroxenite in the origin of the "garnet signature" in MORB: Contrib. Mineral. Petrol. 124, 185-208.

Luhr, J.F., 1997, Extensional tectonics and the diverse primitive volcanic rocks in the western Mexican volcanic belt: Can. Mineral. 35, 473-500

Stern, C.R., Saul, S., Skewes, M.A. and Futa, K., 1989, Garnet peridotite xenoliths from the Pali-Aike alkali basalts of southernmost South America: Proc. 4th Int. Kimberlite Conf. 2, 735-744. 